\title{
The Monumentalization of our Disgrace: Concentration Camps in Postwar Germany
}

\author{
Emily Tran
}

When German forces finally surrendered to the Allies on 8 May 1945, amid the ruins of Europe were dozens of concentration camps, the sites of horrendous atrocity that bore indisputable testament to the crimes of the Nazi state. Today, these concentration camps are memorials, museums, and educational sites. However, in the decades immediately following the war, the uses of these sites and the recognition of what had occurred in the camps remained heavily contested in German public memory. This paper focuses on the evolving uses of the Nazi concentration camps that lay in what would become West Germany, namely Bergen-Belsen, Dachau, Flossenbürg, and Neuengamme beginning in the immediate postwar years through to the $21^{\text {st }}$ century. Given the heavily intertwined nature of memorialization and memory, this is also an examination of the changes in German social memory and public understanding of the Second World War and Nazi atrocities. Indeed, the postwar histories of of Bergen-Belsen, Dachau, Flossenbürg, and Neuengamme are tangible illustrations of the progress of German historical consciousness and reconciliation with the Nazi past.

When American soldiers entered Dachau concentration camp on 28 April 1945, "the first thing that was seen outside the camp was a train of some forty railway cars of all types," filled with "horribly thin corpses [...] each clad in the pajama-like uniform of concentration camps." As $7^{\text {th }}$ US Army Corporal William W. Quinn wrote in his initial report from Dachau, the prisoners had been loaded into the boxcars alive, "expected to be dead by the time they reached Dachau, so that their corpses could be done away with in the famous crematory." Instead, the Allies had arrived before the trains could be unloaded, and were greeted by the stench of death and human refuse and the searing image of "one of the greatest crimes against humanity." ${ }^{3}$ Later that evening, when the SS warehouses were opened for looting, US soldiers watched in shock as the townspeople of Dachau walked along the railroad tracks, indifferent to the piles of broken bodies and starved corpses piled beside them.

The apathy of the Dachau townspeople that night also emerged in the German population as a whole in the postwar years as they, too, averted their eyes from the horrific evidence of Nazi crimes and the brutal

\footnotetext{
${ }^{1}$ William W. Quinn, Dachau (US Army, 1945), 19.

${ }^{2}$ Quinn, Dachau, 19.

${ }^{3}$ Quinn, Dachau, 20.

${ }^{4}$ Harold Marcuse, Legacies of Dachau: The Uses and Abuses of a Concentration Camp, 1933-2001 (Cambridge: Cambridge University Press, 2001), 50.
} 
suffering of their victims. Claiming their own victimization, ignorance, and resistance, the German public forged a distorted and mythical understanding of the Nazi-era German past that served as a usable and palatable foundation upon which to rebuild a nation. In the first decades after the war, these myths powerfully shaped Germans' perceptions of themselves, attitudes towards the victims of Nazi atrocities, and management of the physical sites of their suffering. ${ }^{5}$ It was not until the 1970s that these myths and the paradigm of history that they buttressed began to be dismantled. ${ }^{6}$ In seeking to understand the implications and legacies of such a profound and pervasive misunderstanding of historical wrongs, it is useful to examine the uses of and memorialization efforts at concentration camp sites in the postwar years.

The manner in which memorial sites reveal much more about the needs and goals of their makers than the events they claim to commemorate indicates the dialectical relationship between the political and cultural context of memorials and the memorials themselves. As such, it is appropriate to focus on sites located in a common political entity and established in tribute of a similar event. ${ }^{7}$ This study, then, focuses on the Nazi concentration camps that lay in what would become West Germany, namely Bergen-Belsen, Dachau, Flossenbürg, and Neuengamme, and the evolution of these camps into memorial sites for the victims of the Nazi atrocities committed there. Moving chronologically from the immediate aftermath of the liberation of the camps through to the $21^{\text {st }}$ century, this analysis examines the social, economic, political, cultural factors that shaped collective memory and public understanding, and how this progress, in turn, visibly manifested at concentration camp sites.

Before scrutinizing the postwar uses of Bergen-Belsen, Dachau, Flossenbürg, and Neuengamme, brief consideration of each concentration camp's prewar and wartime history is useful for revealing the circumstances surrounding the existence and operation of the sites. The first of these camps to be established was Dachau. The site, on the outskirts of the Bavarian town of Dachau, was originally World War I-era guns and munitions factory, shuttered after the signing of the Versailles Treaty and subsequently unused through the 1920s. In March of 1933, the armament works was taken over by the Nazis for the purposes of a "collection camp for political prisoners." Along with its place as the first established concentration camp, Dachau was also prominent as it was the first to be under the supervision of Heinrich Himmler, who eventually controlled the entire network of Nazi concentration and extermination camps. Himmler developed Dachau as the model for subsequent Nazi camps, and used the site and its prisoners as a "school of violence" that hosted the initial training of officials including Adolf Eichmann, mastermind of the Final Solution, and Rudolf Höss, commandant of Auschwitz. ${ }^{10}$ Furthermore, it was at

\footnotetext{
${ }^{5}$ Marcuse, Legacies of Dachau, 77.

${ }^{6}$ Marcuse, Legacies of Dachau, 327.

${ }^{7}$ Harold Marcuse, "Memorializing Persecuted Jews in Dachau and Other West German Concentration Camp Memorial Sites," in Memorialization in Germany Since 1945, ed. Bill Niven and Chloe Paver (London: Palgrave Macmillan, 2009), 192.

${ }^{8}$ Marcuse, Legacies of Dachau, 3.

${ }^{9}$ Marcuse, Legacies of Dachau, 21.

${ }^{10}$ Marcuse, Legacies of Dachau, 1-2.
} 
Dachau that the Nazis incarcerated their most prominent prisoners, including the ministers of occupied countries and high-ranking religious leaders. It is estimated that, over the course of its twelve years of existence, 200000 Europeans were imprisoned at Dachau, of whom 41500 were killed. ${ }^{11}$

The second in this group of concentration camps to be established was also located in Bavaria, in the Upper Palatinate region outside the town of Flossenbürg, which had been established in the late $19^{\text {th }}$ century as a workers' village for those mining granite in the newly opened quarries. The townspeople in Flossenbürg welcomed the Nazi seizure of power in 1933, particularly due to the subsequent boom in demand for granite created by the new state construction program. ${ }^{12}$ In March 1938, as part of the SS's reorganization of the concentration camp system to profit from prisoner labour, the Nazis opened a concentration camp at Flossenbürg and populated it with "green triangles," who ranged from serious criminals to those arrested for petty offences. ${ }^{13}$ Some of these "green triangles" became henchmen of the SS as kapos of the camp in a scheme designed to prevent prisoner solidarity, remove any sense of privacy, and foster an environment of constant persecution. ${ }^{14}$ Inmates of Flossenbürg and its satellite camps, who soon included Jews and political prisoners, were forced to work in quarries, for local businesses and agencies, and in the armaments industry. ${ }^{15}$ It is estimated that of the more than 100000 imprisoned during the camp's seven years of operation, one third perished, a proportion twice as high as Dachau's, indicating the extreme brutality of Flossenbürg and its place as "one of the most terrible concentration camps in the German Reich."

Like Flossenbürg, the concentration camp established near the Hamburg village of Neuengamme was also industry-based, this time on the production of bricks. The SS initially purchased the brick factory and surrounding 500000 square metres of land that would become Neuengamme concentration camp in 1938, using the SS-owned company Deutsche Erd-und Steinwerke as a front. In December 1938, Neuengamme concentration camp opened as a satellite camp of Sachsenhausen. After an inspection by Himmler in 1940, the camp was expanded and became an independent camp with its own network of satellite camps, eventually housing Soviet POWs, Jews, and members of the French Resistance. Neuengamme prisoners were forced to work in the site's brick factory and in armament plants run by private industrial companies

\footnotetext{
11 "Introduction," KZ-Gedenkstätte Dachau, accessed 7 December 2015, http://www.kz-gedenkstaette-dachau.de

12 "History: Flossenbürg Concentration Camp." KZ-Gedenkstätte Flossenbürg, accessed 6 December 2015,http://www.gedenkstaette-flossenbuerg.de/en/history/flossenbuerg-concentration-camp/before-1938flossenbuerg-site-of-granite/

${ }^{13}$ Jörg Skriebeleit, “Afterword: Flossenbürg? Never Heard of It,” in Jakub's World: A Boy's Story of Loss and Survival in the Holocaust, Alicia Nitecki and Jack Terry (Albany: State University of New York Press, 2005): 128.

${ }^{14}$ Skriebeleit, "Afterword," 140.

15 "History," KZ-Gedenkstätte Flossenbürg.

${ }^{16}$ Skriebeleit, "Afterword," 141.
} 
Messap and Jastram. ${ }^{17}$ Of the more than 100000 imprisoned at Neuengamme and its 85 satellite camps, at least 26800 are estimated to have been killed at the camp, and another 16100 in evacuation efforts. ${ }^{18}$

Bergen-Belsen was unique among the four camps being studied here in that it was a "detention camp," (Aufenthaltslager), while the others were work camps. ${ }^{19}$ Named for the nearby twin towns of Bergen and Belsen, the Bergen-Belsen site was originally a barracks and training ground for the Germany army between 1935 and 1938. ${ }^{20}$ In June of 1940, the Wehrmacht took control of a camp of huts two kilometers south of the military base, and used the site to hold French and Belgian POWs; this site was expanded the following year to house 21000 Soviet POWs, 14000 of whom had died of starvation, disease, and exposure by April 1942. In 1943, authority was transferred to the SS, and Bergen-Belsen became an "exchange camp" to hold Jews thought by Germans to be valuable to the Allies, and thus considered bargaining chips for prisoner exchanges. ${ }^{21}$ In March 1944, a men's camp was built to house prisoners from other concentration camps who had become too sick or were no longer able to work; later that year, a women's camp was set up to house arrivals from Auschwitz as well as women and children involved in the Warsaw Uprising. Some 52000 are believed to have perished at Bergen-Belsen during its two years as an SS concentration camp, from 1943 to $1945 .^{22}$

The use of Dachau, Flossenbürg, Neuengamme, and Bergen-Belsen as memorial sites and for the purposes of developing collective German memory of the war began in the immediate years after Allied forces liberated the camps between mid-April and early May 1945. The first of these camps to be liberated was Bergen-Belsen, reached by British troops on 15 April 1945. There, they found 53000 people, the vast majority of whom were Jews, living in horrific conditions - jammed into overcrowded barracks, without water nor food, devoid of sanitary facilities, and suffering a typhus epidemic. ${ }^{23}$ Ten thousand corpses were strewn round the camp, and health conditions were so poor that another 13000 would die in the weeks following liberation. ${ }^{24}$ Attempting to minimize the spread of disease, British authorities buried the dead in huge burial pits and torched the wooden prisoners' huts. Though done for good reason, the burning of the wooden huts further contributed to the destruction of evidence of crimes committed at the camp, a process the had begun when SS officials destroyed all camp papers prior to

17 “Timeline,” KZ-Gedenkstätte Neuengamme, accessed 6 December 2015, http://www.kz-gedenkstaetteneuengam me.de/en/history/timeline/

18 "The Total Number of Dead," KZ-Gedenkstätte Neuengamme, accessed 6 December 2015, http://media.offenes-archiv.de/zeitspuren_tht_Zahl_Toten_engl.pdf

${ }^{19}$ Marcuse, "Memorializing," 193.

${ }^{20}$ David Cesarani, “A Brief History of Bergen-Belsen,” in Belsen 1945: New Historical Perspectives, ed. Suzanne Bardgett and David Cesarani (London: Vallentine Mitchell, 2006): 13.

${ }^{21}$ Cesarani, "A Brief History," 14.

22 "Chronology." Gedenkstätte Bergen-Belsen. Accessed 6 December 2015. http://bergen-belsen.stiftungng.de/en/history/chronology.html

${ }^{23}$ Cesarani, "A Brief History," 19.

${ }^{24}$ Marcuse, "Memorializing," 193. 
liberation. ${ }^{25}$ The 29000 remaining survivors of Belsen were transferred to an emergency hospital in the Wehrmacht barracks, which eventually became a Polish and Jewish Displaced Person (DP) camp later that year. ${ }^{26}$ Survivors quickly erected provisional memorials, with the Polish planting a birch cross just one day after liberation, and Jewish survivors raising a provisional memorial over the mass graves in September 1945. The British Military Government soon placed the first memorial sign at Belsen:

This is the site of the infamous Belsen concentration camp, liberated by the British on $15^{\text {th }}$ April 1945. 10, 000 unburied dead were found here, another 13, 000 have since died. All of them victims of the German New Order in Europe and an example of Nazi Kultur. ${ }^{27}$

Notably, no mention is made of the Jewish ancestry of the victims. Indeed, information on the Jewish-centered nature of the Nazi atrocities at concentration camps was not readily available in the West German public sphere until the 1960 s. $^{28}$ Beside the English sign was a second featuring a "clumsy" German translation of the inscription, indicating a British desire to address a German audience as well. ${ }^{29}$ The DP camp at Bergen-Belsen, turned over to United Nations Relief and Rehabilitation Administration (UNRAA) administration in March 1946, remained in use until June 1950, and became the largest site for Jewish DPs with over 11000 residents.

The 90th Infantry Division U.S. Army liberated the Flossenbürg concentration camp just over one week after Bergen-Belsen was liberated, on 23 April 1945. In anticipation of the Allied advance, Nazi officials had ordered the evacuation of both the main and satellite camps earlier in the month as part of attempts to erase all physical evidence of wartime atrocities. Forced to march on foot without food or adequate clothing, thousands of prisoners died from exhaustion or were shot or beaten to death by SS soldiers. So numerous were the dead that a special detachment of prisoners was made to trail the group, burying the bodies of fellow prisoners in shallow graves. Of the 52000 prisoners at Flossenbürg before the death marches, just 1500 of the critically ill were left behind to be liberated by the U.S. Army. ${ }^{31}$ On 3 May 1945, American troops organized the burial of the deceased in the centre of the town of Flossenbürg; all residents of the town were obliged to take part. This cemetery, still in existence, was the first memorial for the victims of Flossenbürg concentration camp. Though the memorial marked the religious identities of the dead, the historical context of their death at the Flossenbürg concentration camp was not referenced. ${ }^{32}$

\footnotetext{
${ }^{25}$ Rainer Schulze, "Forgetting and Remembering: Memories and Memorialisation of Bergen-Belsen." Holocaust Studies 12 no. 1-2 (Summer/Autumn 2006): 217-218.

26 "Chronology," Gedenkstätte Bergen-Belsen.

${ }^{27}$ Marcuse, "Memorialization," 193.

${ }^{28}$ Marcuse, "Memorialization," 193.

${ }^{29}$ Harold Marcuse, "Holocaust Memorials: The Emergence of a Genre," American Historical Review 115: no. 1 (February 2010): 64.

30 "Chronology," Gedenkstätte Bergen-Belsen.

${ }^{31}$ Skriebeleit, "Afterword," 139-140.

${ }^{32}$ Skriebeleit, "Afterword," 145.
} 
The liberated prisoners of Flossenbürg were removed from the former camp in June 1945, and the U.S. Army immediately repurposed the site, setting up the "PWE (Prisoner of War Enclosure) 422" to house SS members until March 1946. The next month, the camp became the UNRAA-administrated "Polish DP Camp Flossenbürg," with old prisoner barracks serving as DP housing. The DPs there, non-Jewish Poles who had never been imprisoned in the concentration camp, attempted to beautify the surroundings by removing the barbed wire fences and planting gardens. ${ }^{33}$ In October 1947, the UNRAA camp was shuttered, and the site became a refugee camp for expellees from Silesia, East Prussia, and the Sudetenland.

Six days after Flossenbürg concentration camp was liberated, Dachau was liberated by American troops. The scenes of boxcars and railway tracks strewn with 2000 corpses as described in the opening paragraph of this paper were a result of the Nazi evacuation of prisoners to Dachau, a southern camp that had been the furthest away from the advancing Allied line. ${ }^{36}$ Along with disposal of bodies, Americans were tasked with caring for the 31000 survivors of the camp. Immediately, camp survivors were divided into national groups and the site took on its first postwar role as a makeshift survivor's camp. ${ }^{37}$ After all liberated survivors left the site by June 1945, Americans repurposed the prisoners barracks into a "War Crimes Enclosure" and interned 30000 officials from the German army and Nazi Party. ${ }^{38}$ From June of 1945 to the summer of 1948, a series of 489 trials involving these inmates was conducted on the camp site, with 672 charges laid against the accused. ${ }^{39}$ Thereafter, the Dachau concentration camp site was returned to the Bavarian government, which originally intended to use the site as a "correctional institution." However, a refugee crisis due to the expulsion of Germans from the Soviet bloc forced the government to convert the site to a residential settlement for 2000 Germans from Czechoslovakia, called Dachau-East. Transformed with apartment, stores, and paved streets, the Dachau concentration camp would remain a residential settlement for 15 years.

Though the barracks, buildings, and land of Dachau concentration camp were put to a variety of uses by the Allied forces and by Bavarian officials, early memorialization efforts, primarily by non-Jewish survivors, did exist. In June 1945, an American-directed effort to build a memorial at Dachau called for "two stone columns fifty feet high, one topped by a cross and the other by the Star of David" to be erected by German civilians and made of marble from Nuremburg stadium. ${ }^{41}$ This memorial was ultimately

\footnotetext{
${ }^{33}$ Skriebeleit, "Afterword," 145-146.

${ }^{34}$ Skriebeleit, "Afterword," 148.

${ }^{35}$ Marcuse, Legacies of Dachau, 51.

${ }^{36}$ Marcuse, Legacies of Dachau, 49.

${ }^{37}$ Marcuse, Legacies of Dachau, 65.

${ }^{38}$ Marcuse, Legacies of Dachau, 66.

39 “1945-Present: History of the Memorial Site," KZ-Gedenkstätte Dachau, accessed 5 December 2015, https://www.kz-gedenkstaette-dachau.de/present.htm

${ }^{40}$ Marcuse, Legacies of Dachau, 3.

41 "GERMANS HONOR VICTIMS: Forced to Build Memorials to 3,500 Dachau Dead," New York Times, 15 June 1945.
} 
scrapped when the project's designer Nazi affiliations were discovered. ${ }^{42}$ As a result, the only physical memorial before 1949 was a tall wooden cross, erected by non-Jewish Poles, on the roll-call square. Another notable memorialization effort in the immediate aftermath of liberation was the exhibition set up in the Dachau crematorium in the fall of 1945. Organized by survivors with support from U.S. personnel, the exhibit focused on the criminal nature of the camps, and featured life-sized mannequins demonstrating SS punishment techniques. Bavarian officials removed the exhibition in $1953 .{ }^{43}$

The final of the four camps under consideration here to be liberated was Neuengamme. On 2 May 1945, mere hours after the last SS soldiers and prisoners had left the camp after burning the last files, the first British Royal Artillery troops arrived at Neuengamme. So complete was the SS evacuation of prisoners to Bergen-Belsen, Sandbostel, and Wöbbelin that the British soldiers reported the camp as "empty." Immediately thereafter, British forces repurposed the site as a camp for Soviet DPs who had been former forced labourers in Hamburg. On 5 June 1945, Neuengamme became an official internment camp and permanent institution, used by the British Military Government to house those subject to automatic arrest in accordance with the Potsdam Agreement. In fall 1946, the site expanded to include a transit camp used to hold British Zone-bound German expellees being screened by British officials. The British-run internment camp was closed in August of 1948, and the site returned to the Bavarian government. Earlier in the year, the brick factory originally bought by the SS ten years prior, around which the concentration camp had been built, was returned to the city of Hamburg; in 1949, the city leased the factory for commercial use to a company that produced lightweight building boards. ${ }^{45}$ Perhaps due to the lack of survivors at Neuengamme when the camp was liberated, no memorialization efforts surfaced in the immediate postwar era.

Whether liberated by British or American forces, Bergen-Belsen, Flossenbürg, Dachau, and Neuengamme were each used sites to hold large groups of people - whether survivors, prisoners of war, or war criminals - in the immediate postwar years. For the Allies, concentration camps were very much functional, efficient spaces available for pragmatic use. ${ }^{46}$ That said, British and American military commanders also recognized the moral depravity of the Nazi regime on display at the concentration camps they liberated, and mounted significant efforts to publicize the evidence of Nazi cruelty and carnage. When British troops arrived at Bergen-Belsen on 15 April, they encountered the first German concentration camp that had not yet been evacuated. ${ }^{47} 33$ rolls of film and more than 200 photographs were taken by members of the British Army's Film and Photographic Unit (AFPU); this work at Belsen would arguably become the most influential and widespread documentation of Nazi concentration camps.

\footnotetext{
${ }^{42}$ Marcuse, "Memorialization," 195.

${ }^{43}$ Marcuse, Legacies of Dachau, 170-173.

44 "Timeline." KZ-Gedenkstätte Neuengamme.

45 "Timeline." KZ-Gedenkstätte Neuengamme.

${ }^{46}$ Skriebeleit, "Afterword," 149.

${ }^{47}$ Marcuse, Legacies of Dachau, 53.
} 
${ }^{48}$ At Dachau, under the orders of SHAEF Commander Eisenhower, American forces deliberately left camp conditions unchanged and organized tours for delegations of congressional representatives, newspaper reporters, and residents from nearby towns. Taken together, the efforts of the AFPU and Eisenhower were an attempt to not only educate the British and American public about "what sort of savages we were dealing with," but to also confront the German people with undeniable evidence of Nazi crimes. ${ }^{49}$ Atrocity photographs, films, and tours were all part of Allied "reeducation" efforts as mounted in the immediate postwar years. Encompassing all channels of mass media, reeducation utilized newspaper articles, large photograph placards, free pamphlets, radio reports, film footage, and public presentations to disseminate images and stories of emaciated prisoners, ash-laden cremation ovens, and heaps of corpses. ${ }^{50}$ In forcing Germans to encounter the atrocities again and again, and repeatedly accusing Germans of responsibility, War Department officials hoped to forge a sense of collective guilt and genuine repentance.

It quickly became clear that the German reaction to Allied re-education was the antithesis of what officials had hoped for. In failing to recognize that Nazi Germany was not a representative democracy based on public accountability similar to the British or American model of politics, planners wrongly assumed that the German public would feel tacit responsibility for the acts of their government officials. Germans, in turn, considered the program a "crude propaganda attempt that selected exceptional circumstances - the conditions of concentration camps at liberation - to justify harsh and unjust policies." ${ }^{52}$ Indeed, German intellectual Alfred Döblin described the German resistance to reeducation attempts thusly:

The reports and the statistics on concentration camps and other horrors that are now being publicized can have an education effect in themselves. But people are simply not inclined to believe them, for it is strangers, foreigners, as a rule, who are reporting the news. ${ }^{53}$

Rather than inspiring a sense of guilt and responsibility and desire for penance, Allied re-education efforts instead fostered in Germans a defensiveness against continued accusations, a numbing to horrific evidence of atrocity, and growing sense of victimization.

The victimization felt by Germans when ceaselessly confronted by atrocity photographs and films in the immediate postwar era was among the three primary responses of Germans as they reacted to the horrific crimes represented by concentration camps such as Bergen-Belsen, Dachau, Flossenbürg, and

\footnotetext{
${ }^{48}$ Toby Haggith, "The Filming of the Liberation of Bergen-Belsen and its Impact on the Understanding of the Holocaust," in Belsen 1945: New Historical Perspectives, ed. Suzanne Bardgett and David Cesarani (London: Vallentine Mitchell, 2006): 89.

${ }^{49}$ Marcuse, Legacies of Dachau, 54-55.

${ }^{50}$ Marcuse, Legacies of Dachau, 61.

${ }^{51}$ Marcuse, Legacies of Dachau, 64.

${ }^{52}$ Marcuse, Legacies of Dachau, 63-64.

53 "Alfred Döblin on the German Population (1946)," German History in Documents and Images, accessed 6 December 2015, http://germanhistorydocs.ghidc.org/sub_document.cfm? document_id=4117
} 
Neuengamme. Described by Harold Marcuse as "founding myths" of the Federal Republic of Germany, these responses included a claim of victimization by Nazis, of ignorance of Nazi atrocities, and of resistance against Nazi overlords. The pervasiveness of these myths informed the German public's resentment of camp survivors, efforts to build the 'clean' camps of rehabilitation portrayed in Nazi propaganda, and desire to remove evidence and forgo recognition of concentration camp atrocities.

The myth of victimization, that is, of Germans' own suffering both in wartime and in the postwar period, was championed by the West German state throughout the 1950s through its emphasis on the plight of German POWs in the Soviet Union and of German expellees from the Eastern Bloc. In fact, the West German state sponsored two collections of eyewitness accounts, the first on "the Expulsion of Germans from East-Central Europe," and the second on the experiences of German prisoners of war. ${ }^{55}$ Some 56000 eyewitness accounts were recorded by the producers of these projects, but notably, no effort was made to seek testimony on experiences of German war aggression. ${ }^{56}$ Furthermore, any mention of Jews served only to establish the horror of the German experience, to measure German suffering in comparison to Jewish suffering. On the misery of Germans under Communists, Maria Zatschek, an expellee from Czechoslovakia, said: "what a bad comedy all this is: nothing is original, a copy of the Hitler regime, again and again we have to hear "Just as you have treated the Jews." "57 The moral equivalence of suffering drawn by Germans between their own experiences and that of Jews in concentration camps not only served to constantly return the focus to German suffering and hardship, but also to conceal the total horror of Nazi atrocities at concentration camps. Survivors' compensation claims for suffering for which Germans felt no responsibility was another source of the sense of victimization in the early postwar decades.

The myth of German ignorance of Nazi atrocities was founded upon Nazi wartime propaganda that promoted concentration camps as "clean camps" for the "containment and correction [of] hardened criminals, $[\ldots]$, Communists, $[\ldots]$ and other enemies of the state, $[\ldots]$ and to educate them to be useful national comrades." In the postwar years, the myth of ignorance of Nazi atrocity was particularly potent when German authorities were given responsibility for former concentration camps and set about on the task of turning the sites into the "clean" prisons of Nazi lore. ${ }^{60}$ This desire to turn concentration camps into correctional institutions was evident in the suggestion of the director of the Hamburg prison authority in 1947 in his proposal to turn the Neuengamme concentration camp site into a state prison:

\footnotetext{
${ }^{54}$ Marcuse, Legacies of Dachau, 76-77.

${ }^{55}$ Robert G. Moeller, "War Stories: The Search for a Usable Past in the Federal Republic of Germany," American Historical Review 101, no. 4 (October 1996): 1024.

${ }^{56}$ Moeller, "War Stories," 1025-1026.

57 "Erlebnisbericht der Frau Maria Zatschek aus Brünn," quoted in Moeller, "War Stories," 1027-1028.

${ }^{58}$ Marcuse, Legacies of Dachau, 76.

${ }^{59}$ Meyers Lexikon, $7^{\text {th }}$ edition, vol. VI, col. 1725, quoted in Marcuse, Legacies of Dachau, 158.

${ }^{60}$ Marcuse, Legacies of Dachau, 159.
} 
Neuengamme concentration camp weighs like a curse on Hamburg's conscience, its honor, and its reputation. Neuengamme's reputation for inhumanity and cruel horrors must be eradicated from the memories about our times. Now the opportunity presents itself to build a model penal reputation. This mark of past shame should be obliterated, and Neuengamme should signify an obligation to recompense past wrongs that we willingly take upon ourselves in that this institution is made into a model facility of humanity renowned the world over.

The desire of this official to write over the shameful Nazi past at Neuengamme with a proper, respectable, prison was realized in 1949 when new prison foundations were laid, and his efforts were so successful that there was no major public opposition to the facility until the late $1960 \mathrm{~s}^{62}$ Lobbying began in the 1980s for the dissolution of the prison, and the state penitentiary at Neuengamme was finally vacated in $2005^{63}$

The veracity of the myth of German resistance against Nazis was demonstrated in campaigns to destroy the remnants and physical evidence of wartime atrocities from concentration camp sites. An instance of such action occurred at Dachau in 1955. Following the Dachau city officials' successful battle to remove the survivor-curated exhibition in the crematorium of the concentration camp in 1953, emboldened city officials pressed for the destruction of the crematorium building in 1955; many in the town claimed that the crematorium had been "built by the U.S. army after the war for propaganda purposes." public opinion was turning, however, and a motion for the closure and destruction of the crematorium in Bavarian parliament was met with vehement protests and ultimately defeated. ${ }^{65}$ The desire to destroy concentration camp structures was also evident at Flossenbürg in the 1950s, to a different outcome. At Flossenbürg, the state memorial transformed the site into a park in a conscious attempt to "soften the memory of the past." At the time, the rest of the camp was being used as a housing settlement and for industry, and the only evidence of the site's concentration camp past was hidden away in a small document centre, away from the public eye.

Tendencies through the late 1940s and 1950s to focus on myths of German victimization, ignorance, and resistance began to give way to new paradigms of critical thought about the recent past beginning in the 1960s. ${ }^{67}$ High profile judicial and legislative cases such as the 1961 trail of Adolf Eichmann in Jerusalem, four major trials of Auschwitz personnel in Frankfurt between 1963 and 1965, and the resulting debate in

\footnotetext{
${ }^{61}$ Gefängnisbehörde to Senate, 21 October 1947, quoted in Marcuse, Legacies of Dachau, 160.

${ }^{62}$ Marcuse, Legaacies of Dachau, 160.

63 "Timeline." KZ-Gedenkstätte Neuengamme.

${ }^{64}$ Marcuse, Legacies of Dachau, 182.

${ }^{65}$ Marcuse, Legacies of Dachau, 184.

66 "What Remains: The Aftermath of the Flossenbürg Concentration Camp." KZ-Gedenkstätte

Flossenbürg, accessed 6 December 2015, http://www.gedenkstaette-flossenbuerg.de/en/ exhibitions/what-remains-the-aftermath-of-the-flossenbuerg-concentration-camp/concept/1

${ }^{67}$ Marcuse, Legacies of Dachau, 205.
} 
the German parliament on the Statute of Limitations on the prosecution of murder led to renewed public interest and greater public knowledge of Nazi atrocities. ${ }^{68}$

Also central to the 1960 watershed moment in German collective memory and public understanding of the Nazi years was the coming of age of a new generation. As Marcuse argues, the "1968er" generation, that of individuals born between 1937 and 1953 and thus the children of the wartime generation, examined the Nazi past as a history of their parents' failures; this generation, motivated by an interest in Anne Frank as spurned by a successful 1957 play and 1959 movie, embarked on pilgrimages to the site of Bergen-Belsen, where Frank died. ${ }^{69}$ The strength young people's interest in Bergen-Belsen was reflected in further development of the site, which in the 1960s underwent extensive landscaping efforts, a cemetery redesign, and the opening of its first Document Building. ${ }^{70}$ The opening of the Dachau Concentration Camp Memorial Site in 1965 is another indication of the increased prominence and interest in wartime atrocities and concentration camps during the decade.

The repudiation of the three founding myths of victimization, ignorance, and resistance began in earnest in the 1970s, as myths and their legacies lost influence as younger generations came of age. The 1978'er generation, born between 1954 and 1966, and grandchildren of the wartime generation, was a particular force. While this age group remained tangibly connected to the Nazi era through the experiences of their grandparents, individuals had enough of a temporal distance so as to not be burdened by any sense of collective guilt. A pivotal event in the young adulthood of the 1978er cohort was the January 1979 broadcast of American mini-series Holocaust. ${ }^{72}$ The film, which portrayed the experiences of the fictional German-Jewish Weiss family during the Holocaust, was heavily publicized in the weeks before its broadcast by television networks in an attempt to stir public debate. Shown on four consecutive nights, the series amassed a viewing audience of more than 20 million: nearly half of the population 14 years of age and older saw at least one segment. ${ }^{73}$ After each episode, viewers were offered the opportunity to phone in and ask questions to live experts, who included historians, political scientists, and concentration camp survivors. Each night, the lines were flooded with thousands of calls; recurring themes included causation and moral judgement as callers repeatedly asked, how "the masses" had "let it happen." This massive public reaction indicated that a taboo had been broken, and that a shift in German understanding of the Holocaust was possible. The emotionally moving humanization of victims of the Nazi atrocities as portrayed in Holocaust was one of the major transformative collective German experiences that encouraged the end of the myth of ignorance of Nazi crimes.

\footnotetext{
${ }^{68}$ Marcuse, Legacies of Dachau, 212-214.

${ }^{69}$ Marcuse, Legacies of Dachau, 297.

70 "Chronology." Gedenkstätte Bergen-Belsen.

71 "1945-Present: History of the Memorial Site.” KZ-Gedenkstätte Dachau.

${ }^{72}$ Marcuse, Legacies of Dachau, 293.

${ }^{73}$ Alf Lüdke, "“Coming to Terms with the Past': Illusions of Remembering, Ways of Forgetting Nazism in West Germany," The Journal of Modern History 65, no. 3 (September 1993): 545.

${ }^{74}$ Lüdke, "Coming to Terms," 547.
} 
The impact of Holocaust on the German consciousness was illustrated in the attendance figures at Dachau that year, which swelled by $55 \%$ to just under 1 million annually. ${ }^{75}$ Over the course of the 70 s, attendance figures grew threefold before plateauing through the $80 \mathrm{~s}$. That the majority of these new visitors were under the age of 25 years old is evidence that the upsurge in interest on the topic of Nazi crimes was driven by a younger generation. That the attendance figures remained steady indicates that the interest fostered in this generation during their youth was strong and sustained. ${ }^{76}$

The second of Marcuse's foundational myths to fall was the myth of victimization, which was dismantled in the 1980s. The continued potency of the myth of German victimization during and after the war, and the slow relinquishing of victimhood was particularly evident during the visit of U.S. President Ronald Reagan to West Germany in 1985. On the official agenda was a visit with Chancellor Kohl to a concentration camp - a crucial indication that, by the mid-80s, the older generation was willing to publicly recognize wartime atrocities - and a visit to a German war cemetery, insisted upon by Kohl as a gesture of reconciliation. ${ }^{77}$ Originally, Reagan and Kohl were to visit Dachau concentration camp; however, local authorities protested that such a visit would serve only to emphasize the dark past of Dachau, and the visit was moved to Bergen-Belsen instead which, having been demolished by liberating troops, was considered "prettier" than the "dirty" camp of Dachau. ${ }^{78}$ Dachau officials' adamancy that the Dachau concentration camp served only to disgrace the otherwise honourable town, and that their concerns resulted in the presidential visit being moved elsewhere, points to the continued strength of mythic victimization. However, this claim of victimization was not unchallenged. Days after the Reagan visit, West German President von Weizsäcker made an address to parliament on the occasion of the $50^{\text {th }}$ anniversary of the end of the war. In it, he forcefully rejected German ignorance and victimization:

Who could remain unsuspecting after the burning of synagogues, the plundering, the stigmatization with the Star of David, the deprivation of rights, the ceaseless violation of human dignity? Whoever opened his eyes and ears and sought information could not fail to notice that Jews were being deported. [...] The initiative for the war [...] came from Germany [...] without Hitler, [the division of Germany] would not have happened at all. ${ }^{79}$

Widely acclaimed both nationally and abroad, Weizsäcker's speech marked a definitive step away from the myths of victimization and ignorance, and the myths' loss of public legitimacy. ${ }^{80}$

The demise of the myth of victimization through the 1980s was reflected in the development of concentration camp memorial sites through an increased emphasis on education and efforts to expand memorialization efforts. At Bergen-Belsen, local teachers and amateur historians demanded a more

\footnotetext{
${ }^{75}$ Marcuse, "Memorialization," 202.

${ }^{76}$ Marcuse, Legacies of Dachau, 333.

${ }_{77}$ Marcuse, Legacies of Dachau, 362.

${ }^{78}$ Marcuse, Legacies of Dachau, 363.

${ }^{79}$ Bitburg, 262-73, quoted in Marcuse, Legacies of Dachau, 365.

${ }^{80}$ Marcuse, Legacies of Dachau, 365.
} 
critical discussion of the role of the camp, and in April 1985, the Landtag of Lower Saxony passed a resolution requesting an update and expansion of the existing memorial. ${ }^{81}$ At Dachau, 1983 saw the addition of administrative and educational staff, and in 1989, the Bavarian parliament passed a resolution to turn the site into a "place of learning.," As the German public moved to a more critical less mythic view of Nazi atrocities, so too did concentration camp memorial sites emphasize their role as places for education.

In the 1990s, the final persisting founding myth, that of German resistance, was renounced through prominent and public means. Given its exoneration of Nazi-era German society, the myth of resistance was the most deeply entrenched and unquestioned, and "defended with special desperation." ${ }^{83}$ The struggle and eventual rejection of this myth was powerfully illustrated when memorialization of Nazi concentration camp atrocities moved from the small towns and remote camp sites to the German capital of Berlin. Efforts began in 1988, and were led by TV talk show hostess Lea Rosh. With a gift of prime real estate in 1993, Helmut Kohl, and later the national and Berlin city governments became involved. The memorial "for the murdered Jews of Europe" proved controversial. ${ }^{84}$ In 1998 author Martin Walser wrote in 1998 that the Berlin monument represented the "paving over the center of our capital to create a nightmare the size of a football field. The monumentalization of our disgrace. ${ }^{85}$ Surely, there is no more evident a repudiation of the innocence of Nazi-era German society in the annihilation of millions than a massive "monumentalization of $[\ldots]$ disgrace" in the centre of the nation's capital.

The rejection of the myth of resistance, and its legacy of resistance to education, took the form of increased government funding, continued educational efforts, and a new commitment to explicit appeals and specific information. ${ }^{86}$ At Bergen-Belsen, 1992 saw the beginning of work on a Book of Remembrance, with the names and autobiographical details of those who perished at the camp. In 2000, the memorial site received federal funding. ${ }^{87}$ At Dachau, 1996 saw the drafting of renovation guidelines that emphasized the site's commitment to experiential learning. ${ }^{88}$ Flossenbürg officially became a historical museum in 1995 and, in Spring 1996, inaugurated an academic research department on the memorial grounds. ${ }^{89}$ Neuengamme received government funding in 1994 for the digitization of prisoner data in an attempt to shed light on the camp's death register, an area long obscured by the Nazis' destruction of records there. ${ }^{90}$ At each of the concentration camp sites, increased government involvement

\footnotetext{
${ }^{81}$ Rainer, "Forgetting and Remembering," 221.

${ }^{82}$ Marcuse, Legacies of Dachau, 388-389.

${ }^{83}$ Marcuse, Legacies of Dachau, 372.

${ }^{84}$ Marcuse, Legacies of Dachau, 376.

85 "Writer Martin Walser Reflects on the Difficulties of Living with German Guilt (October 11, 1998), German History in Documents and Images, accessed 6 December 2015, http://germanhistorydocs.ghi -dc.org/docpage.cfm?docpage_id=3556

${ }^{86}$ Marcuse, "Holocaust Memorials," 84.

${ }^{87}$ Rainer, "Forgetting and Remembering," 200.

${ }^{88}$ Marcuse, Legacies of Dachau, 393.

${ }^{89}$ Skriebeleit, "Afterword," 152.

90 "Timeline." KZ-Gedenkstätte Neuengamme.
} 
in memorialization efforts are evidence of the wider German public's increasing acceptance of and willingness to commemorate the victims of Nazi atrocities.

Through examinations of the Nazi concentration camps of Bergen-Belsen, Dachau, Flossenbürg, and Neuengamme, it is evident that the varied uses of concentration camp sites and the protracted development of memorials there are an apt illustration of the progress of German public understanding and reckoning with the shame and horror of the Nazi past. Having created a mythologized history of victimhood, ignorance, and resistance in the immediate postwar decades, the German public was able to deny the truth of the brutality of Nazi atrocities, the legacies thereof, and the guilt and responsibility of German society. As a result, early concentration camp memorialization efforts were led by survivor groups, if they existed at all. Youth, culture, and politics played especially prominent roles in the move away from these myths and their legacies, beginning in the 1960s and thereafter. Consequently, visits to concentration camp memorials, government funding of sites, and the development of memorials into larger sites grew more and more prevalent. As the sites of Germany's greatest shames and horrors, public interest and support of memorialization efforts at Belsen, Dachau, Flossenbürg, and Neuengamme are indicative of a nation that has and continues to face the legacies of its past wrongs. 
Bibliography

"Alfred Döblin on the German Population (1946)." German History in Documents and Images.

Accessed 6 December 2015. http:/germanhistorydocs.ghidc.org/sub_document.cfm? document id=4117

Cesarani, David. "A Brief History of Bergen-Belsen.” In Belsen 1945: New Historical Perspectives, edited by Suzanne Bardgett and David Cesarani, 13-21. London: Vallentine Mitchell, 2006.

"Chronology." Gedenkstätte Bergen-Belsen. Accessed 6 December 2015. http://bergenbelsen.stiftung-ng.de/en/history/chronology.html

"GERMANS HONOR VICTIMS: Forced to Build Memorials to 3,500 Dachau Dead." New York Times, 15 June 1945.

Haggith, Toby. "The Filming of the Liberation of Bergen-Belsen and its Impact on the Understanding of the Holocaust." In Belsen 1945: New Historical Perspectives, edited by Suzanne Bardgett and David Cesarani, 89-122. London: Vallentine Mitchell, 2006.

"History: Flossenbürg Concentration Camp." KZ-Gedenkstätte Flossenbürg. Accessed 6 December 2015. http://www.gedenkstaette-flossenbuerg.de/en/history/flossenbuergconcentration-camp/before-1938-flossenbuerg-site-of-granite/

“Introduction.” KZ-Gedenkstätte Dachau. Accessed 7 December 2015. http://www.kzgedenkstaette-dachau.de

Lüdke, Alf. "“Coming to Terms with the Past': Illusions of Remembering, Ways of Forgetting Nazism in West Germany." The Journal of Modern History 65, no. 3 (September 1993): 542-572.

Marcuse, Harold. "Holocaust Memorials: The Emergence of a Genre." American Historical Review 115: no. 1 (February 2010): 53-89.

--. Legacies of Dachau: The Uses and Abuses of a Concentration Camp, 1933-2001. Cambridge: Cambridge University Press, 2001.

--. "Memorializing Persecuted Jews in Dachau and Other West German Concentration Camp Memorial Sites." In Memorialization in Germany Since 1945, edited by Bill Niven and Chloe Paver, 192- 204. London: Palgrave Macmillan, 2009.

Moeller, Robert G. "War Stories: The Search for a Usable Past in the Federal Republic of Germany." American Historical Review 101, no. 4 (October 1996): 1008-1048.

Quinn, William W. Dachau. US Army, 1945.

Schulze, Rainer. "Forgetting and Remembering: Memories and Memorialisation of BergenBelsen." Holocaust Studies 12 no. 1-2 (Summer/Autumn 2006): 217-235.

Skriebeleit, Jörg. “Afterword: Flossenbürg? Never Heard of It.” In Jakub's World: A Boy's Story of Loss and Survival in the Holocaust, by Alicia Nitecki and Jack Terry, 121-154. Albany: State University of New York Press, 2005.

“Timeline.” KZ-Gedenkstätte Neuengamme. Accessed 6 December 2015. http://www.kzgedenkstaette-neuengamme.de/en/history/timeline/

“The Total Number of Dead.” KZ-Gedenkstätte Neuengamme. Accessed 6 December 2015. http://media.offenes-archiv.de/zeitspuren_tht_Zahl_Toten_engl.pdf

"Writer Martin Walser Reflects on the Difficulties of Living with German Guilt (October 11, 1998). German History in Documents and Images. Accessed 6 December 2015. http://germanhistorydocs.ghi-dc.org/docpage.cfm?docpage_id=3556

"What Remains: The Aftermath of the Flossenbürg Concentration Camp." KZ-Gedenkstätte Flossenbürg. Accessed 6 December 2015. http://www.gedenkstaette-flossenbuerg.de/en/ exhibitions/what-remains-the-aftermath-of-the-flossenbuerg-concentration-camp/concept/1/

"1945-Present: History of the Memorial Site." KZ-Gedenkstätte Dachau. Accessed 5 December 2015. https://www.kz-gedenkstaette-dachau.de/present.html 